\title{
IMPACT OF HRM PRACTICES TOWARDS THE ORGANIZATIONAL PERFORMANCE AMONG THE MANAGERIAL POSITION EMPLOYEES IN PRIVATE BANKS
}

\author{
SIDHEAKKYA P.G ${ }^{1} \&$ DR.VENNILAASHREE.S ${ }^{2}$ \\ ${ }^{1}$ Ph.D. Research Scholar (P.T), Department of Commerce, Vels University, Pallavaram, Chennai-600 117 \\ ${ }^{2}$ Professor \& Research Supervisor, Department of Commerce, Vels University, Pallavaram, Chennai-600 117
}

\begin{abstract}
The aim of the Study is to know the Impact of HRM Practices on Organizational Performance in Private Banks among managerial employees in Chennai City. The study used both primary sources as well as secondary sources. The primary level sources of the data obtained from the employees of private banks in the study area. The secondary level sources of the study extracted from textbooks, research papers, magazines, and study-related news articles. The study adopted the non-probability Convenience sampling method. The research aims on the study of population of managerial position employees among private sector banks. The responses accumulated through structured questionnaires. Overall, 200 questionnaires are distributed, out of which 190 responses filled and returned. Out of 190 responses, nine responses declined due to irrelevant information presented by the employees. Finally, 181 responses used for the final study. Research established that the factors of HRM practices, namely Rewards and Recognition, Carrier Advancement, Recruitment and selection, and Employee Participation towards the Organizational Performance in private banking sectors in the study region.
\end{abstract}

KEYWORDS: HRM Practices, Organizational Performance, Recruitment and Selection, Training Rewards and Recognition, and Carrier Advancement.

Received: Jun 08, 2020; Accepted: Jun 28, 2020; Published: Aug 29, 2020; Paper Id.: IJMPERDJUN2020949

\section{INTRODUCTION}

Organizational performance is the overall development of an organization (Drucker, 2002). Human Resource is the main significant asset in any firm. Organizations need to administer their employees efficiently and professionally. Human resources play an essential role in any association. It, thus, involves the substantial concentration of the organization so that employees can access employment up to their full possibility (Ahmad \& Schroeder, 2003). Human Resource means human beings or staff or personnel within the frontier of an organization. They are accountable for performing the assignments assigned to them, and they aspire to convene the association objectives and create the profit. Human Resources can offer an aggressive sustainable benefit by giving them particular practices (Huselid, 1995). A firm's achievement is totally based on the people who are operational in the organization. Human Resource believed more critical asset in any organization(Vlachos et al. 2009). In any association, the employees must be delighted similar to an exclusive asset; the organization's assignment will be accomplished in an improved method if their ability would be enlarged. In the occurrence of the competitive surroundings, the accomplishment of any organization depends upon the capability and the quality of their Human Resource and their program and practice (Rehman, 2011). If there are no HRM practices, then the company always faces complexity and not capable to complete in an aggressive society. The firms present and possible HR 
necessary consideration in expansion and the implementation of its planned business sketch (Huselid, 1995). HR comprise individuals, staff, or personnel within or even exterior the border of an association who are accountable for performing the errands assigned to them. The key aspiration of an organization's HR players is to help the organization to achieve its goals. HR assist the organization to create sustainable spirited advantage (Huselid, 1995).

Indian financial area plays a huge role for the monetary advancement of our country. It is the most driving section of the business portion. Banks encourage channel reserve funds to speculations and cheer financial development by allotting reserve funds to ventures that can possibly yield more significant yields. The Indian financial area is seeing a extensive collection of conceivable outcomes and splendid future occasions. The breaking down monetary conditions, depicted by the quick technique for globalization, have completed whole countries of the globe together, without geographic fringes for exchange and business yet with a gigantic measure of openings for work for individuals. Due to swift progress in IT and telecommunication in recent years, the banking area has been experiencing accelerated changes, following several current improvement processes. (Armstrong, 2020) expressed that "serious advantages acknowledged whether an association source is valuable, one of a kind, and costly to copy." HR shows primary since it draws in these models because of uniqueness. Ability workers confinement has transformed into more critical than it composed, and it turned among the best associations approaches about forceful advantages and scholarly productivity with the most significant sources (Juhdi, 2013). Nevertheless, a preponderance of companies has not adequately invested business and improves the practice of HRM is related to HRM systems and employee engagement. As a result, the outcome of this tendency in HRM, to some capacity, has produced employees not motivated to recompense for dynamic behavior, and the groups do not obtain demanded company conclusion. To meet specific difficulties, employers attempting organizational equipment management companies and explain employees by purchasing how it exercise-trained and remarkably familiar employees and improve job performance.

\section{THEORETICAL BACKGROUND OF THE CONCEPTS}

\section{HRM Practices}

HRM methods are not a unique thought. HR systems approach from HRM. It perceived in the 1980s had a theoretical structure consisting of a viewpoint underpinned by various theories (Armstrong, 2020). The HRM is a method that begins from an HR perspective that includes overarching purposes and guiding philosophy to assume in ways by organization characters to authenticity activities. It concentrates on HRM strategies, policies, and practices that contain entire HRM activities engaged in increasing and organizing workforce and in supervision, the relationship of employment(Armstrong, 2020). (Cooper, Wang, Bartram, \& Cooke, 2019) explores the genuine connection among well-being-oriented. Additionally, it concentrates on the social climate negotiated the affiliation among well-being-oriented. Moreover, the study shows there is a positive association among elasticity and employee level of production. The employee flexibility negotiated the association between social environment and employee performance. (Hussain $\boldsymbol{\&}$ Utsho, 2018) specifies that HRM has a considerable collision on the performance of the businesses. The authors conclude that the concerned authorities must be conscious about the smooth function of HR. The HRM practices engage in re innovation of an essential role in the progress of the organization(Leena, Raman, \& Vijayakumar, 2019). (Juhdi, 2013) discussed that the companies could be capable of attaining their purposes based on human capital within HRM to direct and formulate employees to act, perform, and assume in an approach to make the objects. Also, the HRM practices substantial impacts on employee's attention, emotion, and performance that can influence organizational performance. There are various types of 
HRM systems that have been originated from more advanced studies (Rubel, Rimi, Yusliza, \& Kee, 2018; Ueno, 2014).

The dimensions of HRM systems utilized in investigations are various stages and changes. Therefore, the studies specified that HRM practices are unusual in multiple businesses. Nevertheless, there are broad elements used in numerous models of HRM systems with five essential workings Training, PA, CA, RR, Recruitment, and selection (Chand, 2010; Tsaur \& Lin, 2004; Ueno, 2014). These parts are nucleus elements of HRM systems that any management of companies is very involved in, especially in the banking area. Therefore the present study is focused on measuring the HRM practices and its impact on employee engagement in private sector banks in Chennai.

\section{ORGANIZATIONAL PERFORMANCE}

(Lebdaoui \& Chetioui, 2020) show that client assistance quality assumes an interceding job between CRM rehearses (hierarchical and mechanical) and authoritative execution in both regular and Islamic banks. Our outcomes affirm the positive effect of CRM rehearses on hierarchical execution in the two financial structures.

(Sofi \& Devanadhen, 2015) discovered that authoritative culture influences hierarchical execution legitimately and altogether as every social style in particular; bureaucratic, network, severe and imaginative societies have demonstrated remarkable and direct effect on authoritative execution. In any case, dangerous and imaginative societies were the predominant type of societies that have indicated more effect than bureaucratic and network societies.

\section{REVIEW OF LITERATURE}

\section{Recruitment \& Selection}

Recruitment is exercises intended to bring and recognize adequate, capable candidates to link the principalship obligations of the business (Noe et al., 2010; Richardson \& Denton, 2005). Also, the collection is the method of deciding the most suitable and qualified applicant from the potential candidates that are most healthy and appropriate to execute the job, opportunely (McCauley \& Wakefield, 2006). (Phillips \& Phillips, 1998) stated that efficient recruitment and selection aides develop access between the individuals and the business. It presents applicants with proper information or penetration into the job's responsibilities required for them to reach notified choices about their employment.

\section{Training}

Training usually considers the position of behavior devised to enhance the experience, proficiency, and capabilities of people to implement a more suitable competition among employees and attributes of the job(Ives, Smith, \& Patterson, 2005; MILKOVICH, 2008). (Liao \& Chuang, 2004) service training plans to be set "obvious behavioral principles crossways in all perspectives of an altered confrontation." It should also be produced in line with the precise necessities of the service available. Organizations should make individual employees "know and recognize what they do and why to be ready to offer an elevated level of services to the clients." (González \& Garazo, 2006). The association among the training performance and employee engagement is explained by the norm of social exchange presumption (SET), which inspires employees to know the obligation if they appreciate their bank has companies progress. (Karatepe, 2013) the company invests belongings during appropriate training program, employees may counter by attracting themselves to their resposibilities. 


\section{Performance Appraisal}

(Coens \& Jenkins, 2002) PA as a method by which administrators assess, judge, and portray the performance of job assistants over a particularized phase, and the completion of the assessment is maintained by the association for prospective orientation. (Apak, 2016) suggested that organizations provide comments on the outcome of PA to employees' offerings to get better employees' performance since it allows employees to distinguish their nervousness and concentration that hold to conquer their weakness, increase skills, and adhere them towards tasks.

\section{Reward and Recognition}

(Armstrong, 2020) the rewards system is a method of strategy and procedures compensating its employees with their proficiency, involvement, and ability by proving several proper types, levels of salaries, advantages, and other kinds of rewards. The reward scheme induces employees to achieve essential goals. While most significant employees acknowledge monetary prizes for a job well done, several people simply want to be known as a person or an element of a cluster of a good job. (Alfes et al.2013) mentioned that rewards and recognitions strengthens the wanted performances and together organize, behavior outwardly as well as newly joined employees to modify their actions, foremost to superior performance consequences. Awards and recognition are also recognized as critical applications that triumphant organizations employ to improve employee engagement (Vance, 2006).

\section{Career Advancement}

(Herzberg, 1966) explained that career advancement is the extent to which a firm presents thee forecasts for improvement of workforce career and employees to have a successful career pathway steps within their organizations. The theory of career advancement explained as a stage that supports employees to vision further than their modern works and makes available for more positive future circumstances within their commerce. If the company executes career progression possibilities to employees, it triggers employees' tangible approaches and psychological fortification and creates them more stimulated, dedicated, and fanatical towards their occupation (Aktar \& Pangil, 2017).

\section{Employee Participation}

Employee participation is one of the pronouncement progression in which people are committed. (Heery \& Noon, 2008). Demands whether they are consulted independently or as an alignment by their planner, who then constructs the termination, or they split the closing decision agreed with the manager, or employees assigned accountability for formative by the manager (Al., 2010). According to (Cantor, 2012), employee contribution led to an enlarged human being combined into the associations and employees become more engaged in employment. Employee participation creates employees to understand the essential need of originality and offer a viable and imaginative resolution for jobs through transformed associations with the workforce that improve higher levels of their behavior outcome (Marchington \& Kynighou, 2012).

\section{Information Sharing}

(Wood, 2007) defined that information sharing as,it affiliates within an association to gain truthful information concerning business consequences, customer criticism, and excellence. (Chiang et al. 2008) disputed that as employees feel essential information allotment to employees stimulated their work to present towards the realization of the organization's principles. Frontline employees explain the connection linked to the business and its clients. They regularly contact clients and accept customers' replies to the organization's merchandise or services. Regarding the banks, when customers anticipate exploring 
more information (e.g., credit card, balance checking, loans), they generally address workers at the frontlines (e.g., Customer service officer, teller, individual banker).

\section{OBJECTIVES OF THE STUDY}

To examine the impact of HRM practice, i.e., Recruitment \& Selection, Training, Performance appraisals, Rewards and Recognition, Career Advancement, and Employee Participation, towards the Employee Engagement among managerial level in the private banking sector in Chennai city.

\section{METHODOLOGY}

The present paper's aim is to measure the Impact of HRM Practices towards Organizational performance in Private Banks in Chennai. The study used both primary sources as well as secondary sources. The secondary sources of the study are extracted from the textbooks, research papers, magazines, and study-related news articles the primary sources of the data obtained from the managerial position employees of private banks. The study adopted a non-probability sampling method. The study used a convenience sampling method the target population of this study managerial position employees of private banks. The responses are accumulated through structured questionnaires. Overall, 200 questionnaires are distributed, out of which 190 responses filled and returned back. Out of 190 responses, nine responses are declined due to irrelevant information presented by the employees. Finally, 181 responses used for the final study. The HRM practices variables are adopted from (Cesário, 2015; Gillani, Iqbal, Akram, \& Rasheed, 2018; Karatepe, Yavas, \& Babakus, 2007). The variables are used by the above-mentioned authors. The responses are accumulated five points Likert scale range from strongly agree to disagree strongly. The statistical tools used for the present research is Karl Pearson correlation and Structural Equation Modeling.

\section{RESULTS AND DISCUSSION}

Table 1: Personal Profile of Managers

\begin{tabular}{|c|c|c|}
\hline & Frequency & Percent \\
\hline \multicolumn{3}{|c|}{ Gender } \\
\hline Male & 93 & 51.4 \\
\hline Female & 88 & 48.6 \\
\hline Total & 181 & 100.0 \\
\hline \multicolumn{3}{|c|}{ Age (Years) } \\
\hline Up to 35 & 42 & 23.2 \\
\hline $35-40$ & 49 & 27.1 \\
\hline $40-45$ & 59 & 32.6 \\
\hline Above 45 years & 31 & 17.1 \\
\hline Total & 181 & 100.0 \\
\hline \multicolumn{3}{|c|}{ Marital Status } \\
\hline Single & 41 & 22.7 \\
\hline Married & 140 & 77.3 \\
\hline Total & 181 & 100.0 \\
\hline \multicolumn{3}{|c|}{ Educational Qualification } \\
\hline Under-Graduate & 51 & 28.2 \\
\hline Post-Graduate & 63 & 34.8 \\
\hline Professional & 67 & 37.0 \\
\hline Total & 181 & 100.0 \\
\hline \multicolumn{3}{|c|}{ Annual CTC } \\
\hline Up to 6 Lakhs & 60 & 33.1 \\
\hline Rs.6.1 - 8.0 Lakhs & 84 & 46.4 \\
\hline
\end{tabular}


Table 1: Contd.,

\begin{tabular}{|l|c|c|}
\hline Above 8.0 Lakhs & 37 & 20.4 \\
\hline Total & $\mathbf{1 8 1}$ & $\mathbf{1 0 0 . 0}$ \\
\hline \multicolumn{1}{|c|}{ Designation } & & \\
\hline Branch manager & 24 & 13.3 \\
\hline Assistant manager & 38 & 21.0 \\
\hline Marketing Manager & 30 & 16.6 \\
\hline System Manager & 39 & 21.5 \\
\hline HR Manager & 28 & 15.5 \\
\hline Investment Manager & 22 & 12.2 \\
\hline Total & $\mathbf{1 8 1}$ & $\mathbf{1 0 0 . 0}$ \\
\hline
\end{tabular}

Table 1 shows the personal profile of managerial position employees in private sector banks in Chennai city. Out of 181 managers, $51.4 \%$ of managerial position employees are male, and $48.6 \%$ are female category. Regarding Age group, the majority of $32.6 \%$ of the managerial position employees are in the age group of $40-45$ years, and $27.1 \%$ of the managerial position employees are in the age group between 35-40 years. The results also reveal that $23.2 \%$ of the managerial position employees are in the age group of up to 35 years, and $17.1 \%$ of the managerial position employees are in the age group of above 45 years. Marital status concern, majority $77.3 \%$ of the managerial position employees are married, and $22.7 \%$ of the managerial position employees are single category. The frequency results also reveal that the majority $37 \%$ of the managerial position employee's educational background is professional, followed by $34.8 \%$ of the managerial position employee's educational background is post-graduate, and $28.2 \%$ of the employee's educational background is under-graduates. Regarding Annual CTC's concern, 46.4\% of the managerial position employees' annual CTC is Rs.6.1 - 8.0 lakhs, followed by $33.1 \%$ of the managerial position employees' annual CTC is Up to 6 Lakhs, and $20.4 \%$ of the managerial position employees annual CTC is above 8.0 lakhs.

\section{Null Hypothesis 1}

There is no association between factors and HRM practices among the managerial position employees in private sector banks in Chennai city.

Table 2: Karl Pearson Correlation for Association between HRM Factors and HRM Practices

\begin{tabular}{|c|c|c|c|c|c|c|}
\hline & $\begin{array}{l}\text { Recruitment and } \\
\text { Selection }\end{array}$ & $\begin{array}{c}\text { Performance } \\
\text { Appraisal }\end{array}$ & $\begin{array}{l}\text { Reward and } \\
\text { Recognition }\end{array}$ & $\begin{array}{c}\text { Carrier } \\
\text { Advancement }\end{array}$ & $\begin{array}{c}\text { Employee } \\
\text { Participation }\end{array}$ & $\begin{array}{c}\text { HRM } \\
\text { Practices }\end{array}$ \\
\hline \multirow{3}{*}{$\begin{array}{l}\text { Recruitment and } \\
\text { Selection }\end{array}$} & 1 & $.495^{* * *}$ & $.364^{* * *}$ & $.347^{* * *}$ & $.392^{* * *}$ & $.421^{* *}$ \\
\hline & & .000 & .000 & .000 & .000 & .000 \\
\hline & 181 & 181 & 181 & 181 & 181 & 181 \\
\hline \multirow{3}{*}{$\begin{array}{l}\text { Performance } \\
\text { Appraisal }\end{array}$} & $.495^{* * *}$ & 1 & $.543^{* *}$ & $.530^{* * *}$ & $.499^{* *}$ & $.429^{* * *}$ \\
\hline & .000 & & .000 & .000 & .000 & .000 \\
\hline & 181 & 181 & 181 & 181 & 181 & 181 \\
\hline \multirow{3}{*}{$\begin{array}{l}\text { Reward and } \\
\text { Recognition }\end{array}$} & $.364^{* * *}$ & $.543^{* *}$ & 1 & $.660^{* * *}$ & $.624^{* * *}$ & $.599^{* *}$ \\
\hline & .000 & .000 & & .000 & .000 & .000 \\
\hline & 181 & 181 & 181 & 181 & 181 & 181 \\
\hline \multirow{3}{*}{$\begin{array}{l}\text { Carrier } \\
\text { Advancement }\end{array}$} & $.347^{* * *}$ & $.530^{* * *}$ & $.660^{* * *}$ & 1 & $.599^{* *}$ & $.493^{* * *}$ \\
\hline & .000 & .000 & .000 & & .000 & .000 \\
\hline & 181 & 181 & 181 & 181 & 181 & 181 \\
\hline \multirow{3}{*}{$\begin{array}{l}\text { Employee } \\
\text { Participation }\end{array}$} & $.392^{* * *}$ & $.499^{* * *}$ & $.624^{* * *}$ & $.599^{* * *}$ & 1 & $.494^{* *}$ \\
\hline & .000 & .000 & .000 & .000 & & .000 \\
\hline & 181 & 181 & 181 & 181 & 181 & 181 \\
\hline \multirow{3}{*}{ HRM Practices } & $.421^{* * *}$ & $.429^{* * *}$ & $.599^{* *}$ & $.493^{* *}$ & $.494^{* *}$ & 1 \\
\hline & .000 & .000 & .000 & .000 & .000 & \\
\hline & 181 & 181 & 181 & 181 & 181 & 181 \\
\hline
\end{tabular}

Note: ${ }^{* *}$ denotes significant at $1 \%$ level. 
Table 2 depicts the results of Karl Pearson Correlation for Association between HRM factors and HRM Practices among the managerial position employees in private sector banks in Chennai city. Since the p-value for factors and HRM practices is $<0.01$, therefore the proposed null hypothesis rejected at $1 \%$ level and confirmed that the factors of HRM namely Recruitment and Selection, Performance Appraisal, Reward and Recognition, Carrier Advancement, Employee Participation significantly associated with the HRM practices in private sector banks in the study region.

Multiple Regression Analysis on Impact of HRM Practices on Organizational Performance among the Managerial Position Employees in private sector banks in Chennai city

The multiple regression analysis techniques used to test whether there is any impact of HRM practices on Organizational Performance among the managerial position employees in Chennai city. The regression analysis used both an independent and dependent variable. The independent variables model is, i.e., Performance appraisal, Rewards and Recognition, Carrier Advancement, Recruitment and selection, and Employee Participation. The dependent variable of the regression analysis is organizational performance. The hypothesized model is whether the HRM practices, namely Performance appraisal, Rewards and Recognition, Carrier Advancement, Recruitment and selection, and Employee Participation, influence on organizational performance among the managerial position employees in the private banking sector.

Table 3 shows the model summary of regression analysis of the impact of HRM practices on Organizational performance among the managerial position employees in private sector banks in the study region. The R-value of the model is 0.632 . It indicates that there is a good relationship between HRM factors and Organizational performance among the managerial position employees. The $\mathrm{R}^{2}$ value of the model is 0.399 ; it indicates that the independent variables explain $39.9 \%$ to the dependent variable, and the model is best fitted up to $39.9 \%$.

Table 3: Model Summary

\begin{tabular}{|c|c|c|c|c|}
\hline Model & R & R Square & Adjusted R Square & Std. Error of the Estimate \\
\hline 1 & $.632^{\mathrm{a}}$ & .399 & .382 & .55410 \\
\hline
\end{tabular}

Table 4 depicts the results of the Analysis of variance tests for the Impact of HRM Practices on Organizational Performance. The value of $\mathrm{F}$ is statistically significant at a level of 0.05 or less, and this suggests a linear relationship between the variables. Statistical significance at a .05 level means there is a 95 percent chance that the relationship between the variables is not due to chance. On the other hand, the value of the $\mathrm{P}$ is less than 0.05 , then it will be significant, and the hypothesis which stated will be accepted. The significance level must be less than .05, and it shows that independent variables how much explain the effect of the dependent variable. After that, $\mathrm{F}=23.277$ and $\mathrm{P}=0.001$ are statistically significant.

Table 4: ANOVA Test for Impact of HRM Practices on Organizational Performance

\begin{tabular}{|l|l|c|c|c|c|c|}
\hline \multicolumn{2}{|l|}{ Model } & Sum of Squares & df & Mean Square & F & Sig. \\
\hline \multirow{3}{*}{1} & Regression & 35.734 & 5 & 7.147 & \multirow{2}{*}{23.277} & \multirow{2}{*}{$.000^{\mathrm{b}}$} \\
\cline { 2 - 5 } & Residual & 53.730 & 175 & .307 & \\
\cline { 2 - 4 } & Total & 89.464 & 180 & & \\
\hline a. Dependent Variable: Organizational Performance \\
b. Predictors: (Constant), Employee Participation, Recruitment and Selection, Reward and \\
Recognition, Performance Appraisal, Carrier Advancement \\
\hline
\end{tabular}


Table 5: Coefficients

\begin{tabular}{|c|c|c|c|c|c|}
\hline & \multicolumn{2}{|c|}{$\begin{array}{c}\text { Unstandardized } \\
\text { Coefficients }\end{array}$} & \multirow{2}{*}{$\begin{array}{c}\begin{array}{c}\text { Standardized } \\
\text { Coefficients }\end{array} \\
\text { Beta }\end{array}$} & \multirow[t]{2}{*}{$\mathbf{T}$} & \multirow[t]{2}{*}{ Sig. } \\
\hline & B & Std. Error & & & \\
\hline (Constant) & .726 & .335 & & 2.165 & 0.032 \\
\hline $\begin{array}{l}\text { Recruitment and } \\
\text { Selection }\end{array}$ & .183 & .092 & .132 & 2.004 & $0.047^{*}$ \\
\hline Performance Appraisal & .032 & .078 & .032 & .409 & 0.683 \\
\hline \begin{tabular}{|l|} 
Reward and \\
Recognition
\end{tabular} & .185 & .075 & .178 & 2.461 & $0.015^{*}$ \\
\hline Carrier Advancement & .305 & .076 & .318 & 3.992 & $0.000 * *$ \\
\hline Employee Participation & .156 & .075 & .164 & 2.087 & $0.038 *$ \\
\hline
\end{tabular}

Table 5 exhibits the reveals the Coefficients of the Regression model of Impact of HRM Practices on Organizational Performance among the managerial position employees in private banks in Chennai city. The $\mathrm{t} \&$ p-value of the impact of Recruitment and Selection on Organizational Performance is $2.165 \& 0.047$. The p-value is <0.01, in indication of the above it supports the hypothesis and concluded that Recruitment and Selection significantly influencing the organizational performance among the managerial position employees in Chennai city. The $t \&$ p-value for of impact of performance appraisal on Organizational Performance is $.409 \& 0.683$. The p-value is $>0.05$; it indicates that performance appraisal does not influence the organizational performance. The $\mathrm{t} \& \mathrm{p}$-value for of impact of Reward and Recognition on Organizational Performance is $2.461 \& 0.015$. The p-value is $<0.05$; it indicates that Rewards and Recognition influencing the organizational performance. The t \& p-value for of impact of Carrier Advancement on Organizational Performance is $3.992 \& 0.000$. The $\mathrm{p}$-value is $<0.01$; it indicates that Rewards and Recognition influencing the organizational performance. The $t \&$ p-value for of impact of Employee Participation on Organizational Performance is $2.087 \& 0.038$. The p-value is $<0.05$; it indicates that Employee participation significantly influencing organizational performance.

\section{CONCLUSIONS}

The study concentrated on measuring the Impact of HRM Practices towards the Organizational Performance among the managerial position employees in private banks in Chennai City. It is observed from the study, the components of HRM practices, namely Recruitment and Selection, Performance Appraisal, Rewards and Recognition, Carrier Advancement, and Employee Participation, had a significant relationship with the HRM practices. It creates team building, team spirit among the employees. It leads to enhancing the efficiency level of the organization. In addition, it is also concluded that the factors of HRM practices, namely, Rewards and Recognition, Carrier Advancement, Recruitment and selection, and Employee Participation relates towards employee engagement in private banking sectors in the study region.

\section{REFERENCES}

1. Ahmad, S (2003). The impact of HRM practices on operational performance. Journal of Operations Management, 21(1), 1943.

2. Aktar, A., \& Pangil, F. (2017). The relationship between employee engagement, HRM practices \& perceived

3. Al., W. et. (2010). The Oxford handbook of participation in organizations. Oxford University Press.

4. Alfes, K., Shantz, A., Truss, C., \& Soane, E. (2013). The link between perceived human resource.

5. Apak. (2016). Performance appraisal and a field study. Procedia-Social and Behavioral Sciences, 229, $104-114$. 
6. Armstrong. (2020). Armstrong's handbook of human resource management practice. Kogan Page Publishers.

7. Cantor. (2012). Engagement in environmental behaviors among supply chain management employees Journal of Supply Chain Management, 48(3), 33-51.

8. Cesário, F. J. S. (2015). Employees perceptions of the importance of human resources management practices. Research Journal of Business Management, 9, 470-479.

9. Chand, M. (2010). The impact on HRM practices of service quality, customer satisfaction and performance. Journal of Human Resource Management, 21(4), 551-566.

10. Chiang, C.-F., Jang, S., Canter, D., \& Prince, B. (2008). An expectancy theory model for hotel employee motivation: International Journal of Hospitality \& Tourism Administration, 9(4), 327-351.

11. Coens, T., \& Jenkins, M. (2002). Abolishing performance appraisals: Why they backfire and what to do instead. BerrettKoehler Publishers.

12. Cooper, B et al. (2019). Well-being-oriented HRM practices and employee performance in the Chinese banking sector: The role of social climate and resilience. Human Resource Management, 58(1), 85-97.

13. Drucker, P. (2002). The discipline of innovation. Harvard Business Review, 80, 95-104.

14. Gillani, S. M. F., Iqbal, S., Akram, S., \& Rasheed, M. (2018). Specific antecedents of employees' knowledge sharing behavior. Journal of Information and Knowledge Management Systems.

15. González, J. V., \& Garazo, T. G. (2006). Structural relationships between organizational service orientation, contact employee job satisfaction and citizenship behavior. International Journal of Service Industry Management.

16. Gremler. (2008). Rapport-building behaviors used by retail employees. Journal of Retailing, 84(3), 308-324.

17. Heery, E., \& Noon, M. (2008). A dictionary of human resource management. OUP Oxford.

18. Herzberg, F. (1966). Work and the nature of man. Cleveland. World, 290, 339-341.

19. Huselid, M. A. (1995). The impact of HRM practices on turnover, and corporate financial performance. Academy of Management Journal, 38(3), 635-672.

20. Hussain, M. T., \& Utsho, M. I. (2018). Measuring the Casual Relationship Between the HRM Practices and Organizational Performance in Selected Commercial Banks in Bangladesh. International Journal of Advanced Multidisciplinary Scientific Research (IJAMSR) ISSN: 2581-4281 Vol, 1, 34-42.

21. Ives, D. T., Smith, D. R. R., \& Patterson, R. D. (2005). Discrimination of speaker size from syllable phrases. Acoustical Society of America, 118(6), 3816-3822.

22. Juhdi. (2013). HR practices and turnover intention. The International Journal of HRM, 24(15), 3002-3019.

23. Karatepe, O. M. (2013). High-performance work practices, work social support and their effects on job embeddedness and turnover intentions. International Journal of Contemporary Hospitality Management.

24. Karatepe, O. M., Yavas, U., \& Babakus, E. (2007). The effects of customer orientation and job resources on frontline employees' job outcomes. Services Marketing Quarterly, 29(1), 61-79.

25. Lebdaoui, H.(2020). Service quality \& organizational performance in the banking industry. International Journal of Bank Marketing. 
26. Leena, R., Raman, G. ., \& Vijayakumar. (2019). A Study on HRM Practices In Select Public and Private Sector Life Insurance Companies in chennai City. The International Journal of Analytical and Experimental Modal Analysis, 11(10), $2921-2142$.

27. Liao, H., (2004). Investigation of factors influencing employee service performance \& customer outcomes. Academy of Management Journal, 47(1), 41-58.

28. Marchington, M., \& Kynighou, A. (2012). The dynamics on employee involvement \& participation during turbulent times. Human Resource Management, 23(16), 3336-3354.

29. McCauley, C.(2006). Talent management in the 21 st century: The Journal for Quality and Participation, 29(4), 4.

30. Milkovich, G. (2008). T; Boudreau, J, W. Administração de Recursos Humanos. São Paulo: Atlas.

31. Noe, M., Bach, R., Prusseit, W., Willén, D., Gold-acker, W., Poelchau, J., \& Linke, C. (2010). Conceptual study of superconducting urban area power systems. Journal of Physics: Conference Series, 234(3), 32041.

32. Praveenkumar, S. "The Service Quality Gap Analysis-A Study on Selected Commercial Banks in Madurai." International Journal of Business Management \& Research (IJBMR), 6 (1), 65-74. Ergonomics Principles for Customer Satisfaction (2016).

33. Phillips, M., \& Phillips, T. (1998). Windrush: the irresistible rise of multi-racial Britain. Harpercollins Canada.

34. Rehman, M. S. (2011). Exploring the impact of HRM on organizational performance. Journal of Business Studies Quarterly, 2(4), 1 .

35. Richardson, P., \& Denton, D. K. (2005). How to create a high-performance team. Human Resource Development Quarterly, $16(3), 417-423$.

36. Rubel, M. R. B., Rimi, N. N., Yusliza, M.-Y., \& Kee, D. M. H. (2018). High commitment HRM practices and employee service behaviour: Trust in management as mediator. IIMB Management Review, 30(4), 316-329.

37. Sattar, MD Abdus. "Corporate Social Responsibility in Disaster Risk Management: A Study on Some Selected Private Commercial Banks of Bangladesh." International Journal of Environment, Ecology, Family and Urban Studies 7.5 (2017): 718.

38. Sofi, M. A., \& Devanadhen, K. (2015). Impact on Organizational Culture of Organizational Performance. Journal of Innovative Research \& Development, 4(9), 34-44.

39. Suan. (2014). An empirical investigation into the influence of HRM practices on work engagement. Journal of Culture, Tourism and Hospitality Research.

40. Toppur, Badri, and P R Ramakrishnan. "Data Envelopment Analysis of Indian Public-Sector-Undertaking Banks and Their Current Ranking." International Journal of Mechanical and Production Engineering Research and Development (IJMPERD) 8. 4, Dec 2018, 241-247

41. Tsaur, S.-H., \& Lin, Y.-C. (2004). Promoting service quality in tourist hotels: Tourism Management, 25(4), 471-481.

42. Qazi, Sayeeduzzafar, and Mohammad Saleh Miralam. "Human Resources Management Practices and Job Satisfaction in Critical Economy: An Empirical Study of Private Banking Sector of Saudi Arabia." International Journal of Business Management and Research 7.6 (2017): 43-52.

43. Ueno, A. (2014). Developing a conceptual model illustrating how HRM practices support each other in order to improve service quality. Procedia-Social and Behavioral Sciences, 148, 24-31.

44. Vance, R. J. (2006). Employee engagement and commitment. SHRM Foundation, 1-53. 

Managerial Position Employees in Private Banks

45. Vlachos, P. A., Tsamakos, A., Vrechopoulos, A. P., \& Avramidis, P. K. (2009). Corporate social responsibility: attributions, loyalty, and the mediating role of trust. Academy of Marketing Science, 37(2), 170-180.

46. Wood. (2007). Work enrichment and employee voice in human resource management-performance studies. The International Journal of Human Resource Management, 18(7), 1335-1372. 

